\title{
Long-term trends (1989-2013) in the seabird community breeding in the lagoon of Venice (Italy)
}

\author{
Francesco Scarton ${ }^{1 *}$, Roberto Valle ${ }^{2}$
}

\begin{abstract}
The community of seabirds breeding in the lagoon of Venice, one of the largest around the Mediterranean, was monitored over the 1989-2013 period. Six species have been recorded (Larus michahellis, Chroicocephalus ridibundus, Larus melanocephalus, Sternula albifrons, Sterna hirundo, Sterna sandvicensis). Over the study period, 346 colonies were surveyed; they were located on saltmarsh islets, dredge islands and other artificial sites, in descending order of importance. Beaches were used only at the beginning of the survey. About 4,900 pairs bred in the 2009-2013 years. The community has been always dominated by L. michahellis; in the 2009-2013, this species and $S$. sandvicensis comprised about $70 \%$ of the total. The longterm trends show moderate increase in the size of the whole community. Contrasting trends were observed in different species, with L. michahellis, S. albifrons and S. sandvicensis stable or increasing, whereas $C$. ridibundus and $S$. hirundo were declining. The number of pairs nesting on artificial sites increased over the last 15 years, while those on saltmarsh islets decreased correspondingly. This was possibly a response to the increase of mean sea level and storminess observed in the last twenty-five years. S. albifrons and S. sandvicensis populations reached national importance; the population of the latter species is noteworthy at a Mediterranean level.
\end{abstract} islands.

Key words: Laridae, Sternidae, Colonies, Saltmarshes, Dredge

Riassunto - Cambiamenti a lungo termine (1989-2013) nella comunità di uccelli marini nidificante in laguna di Venezia.

Le colonie di uccelli marini nidificanti nella laguna di Venezia, una delle più grandi dell'intero Mediterraneo, sono state censite ininterrottamente dal 1989 al 2013. Le 346 colonie censite erano ubicate su barene, "barene artificiali" ed altri siti artificiali; quasi nullo l'utilizzo di spiagge naturali. Il maggior uso di siti artificiali è in possibile relazione con l'osservato aumento del livello medio mare e della frequenza di alte maree primaverili-estive. Hanno nidificato sei specie (Larus michahellis, Chroicocephalus ridibundus, Larus melanocephalus, Sternula albifrons, Sterna hirundo, Sterna sandvicensis), con una media di 4.800 coppie negli ultimi anni. La comunità nidificante è sempre stata

'SELC Soc. Coop., via dell'Elettricità 3/d, 30175 Marghera (VE), Italia.

${ }^{2}$ Rialto, 571. S. Polo, 30125 Venezia, Italia.

E-mail: robertovalle@libero.it

* Corresponding author: scarton@selc.it

(C) 2016 Francesco Scarton, Roberto Valle

Received: 31 March 2015

Accepted for publication: 14 September 2015 dominata numericamente dal gabbiano reale; nel 2009-2013 le coppie di questa specie e del beccapesci costituivano circa il $70 \%$ del totale. Il trend sul lungo periodo (1989-2013) indica una crescita moderata del totale coppie nidificanti. L. michahellis, S. albifrons e $S$. sandvicensis risultano stabili o in incremento, mentre $C$. ridibundus and $S$. hirundo risultano in diminuzione. Le popolazioni di $S$. albifrons e $S$. sandvicensis hanno rilevanza a livello nazionale, quella di $S$. sandvicensis anche a livello internazionale. ciali.

Parole chiave: Laridi, Sternidi, Colonie, Barene, Barene artifi-

\section{INTRODUCTION}

Long-term studies, i.e. which span over at least ten years according to Lindenmayer \& Likens (2010), of animal populations have been often considered of paramount importance in understanding frequency, duration and amplitude of variations in the ecological systems (O'Connnor, 1991; Sergeant et al., 2012). For instances, only long-term studies on distribution and density of animal populations highlighted the effects of climate changes (Clutton-Brock $\&$ Sheldon, 2010). In particular, monitoring of bird populations is important if the species concerned are of conservation relevance and the sites on which they depend should be managed or preserved effectively (Atkinson et al., 2006); as pointed out by Tourenq et al. (2000), management decisions based on short-term studies may not reflect the biology of the species involved.

Most of the seabird (Laridae and Sternidae) species nesting in the lagoon of Venice (Italy) are of conservation concern and they are listed in the Annex 1 of the EC 147/2009 Birds Directive; moreover, due to its importance for birds, the Venice Lagoon has been recognized since 2007 as a Special Protection Area, according to the abovementioned Directive. The occurrence of seabird colonies is known here from historic times, but the first surveys took place only in 1983-1984 (Fasola, 1986). After that survey, since 1989 counts of the colonies have been performed without interruption, resulting in one of the longest and regular breeding bird survey made in Italy (Scarton, 2005, 2010). Part of the lagoon of Venice is subjected to a heavy human pressure, and saltmarshes, beaches and man-made sites are used to a different degrees by nesting seabirds, giving the opportunity of comparing use of multiple nesting sites over a range of different habitats and boundary conditions. Moreover, during our monitoring we docu- 
mented the new settlement of species, which never breed before in the study area, an event considered extremely rare by seabird ecologists (Oro \& Ruxton, 2001).

With this paper we aim to present the results gained in the years 1989-2013, with a description of some populations' characteristics. Along with analysis of the population trends over a long (1989-2013) period for each species, the observed changes in colony site use and distribution over the study area will be discussed. Since during the surveys no detailed data were collected about important parameters such as diet of adults and chicks, reproductive success and preys' availability and abundance, a detailed analysis of the causal factors of the observed changes is beyond the scope of this work.

\section{MATERIALS AND METHODS}

\section{Study area}

The Venice Lagoon is among the largest (55,000 ha) coastal lagoon around the Mediterranean, located along the Adriatic Sea, at $45^{\circ} 26^{\prime}$ N, $12^{\circ} 19^{\prime}$ E (Fig. 1). Two barrier islands, named Lido and Pellestrina and the Cavallino peninsula, each about $10 \mathrm{~km}$ long, separate the lagoon from the sea. These two islands and the peninsula feature beaches and dunes, but most of these are heavily urbanized and the seashores are used throughout the year by sunbathers and visitors. A large part of the lagoon consists of an open water body (about 40,000 ha), with peripheral fish farms for an additional 10,000 ha along the borders. The mean depth of the lagoon is $1.1 \mathrm{~m}$ (all the elevations

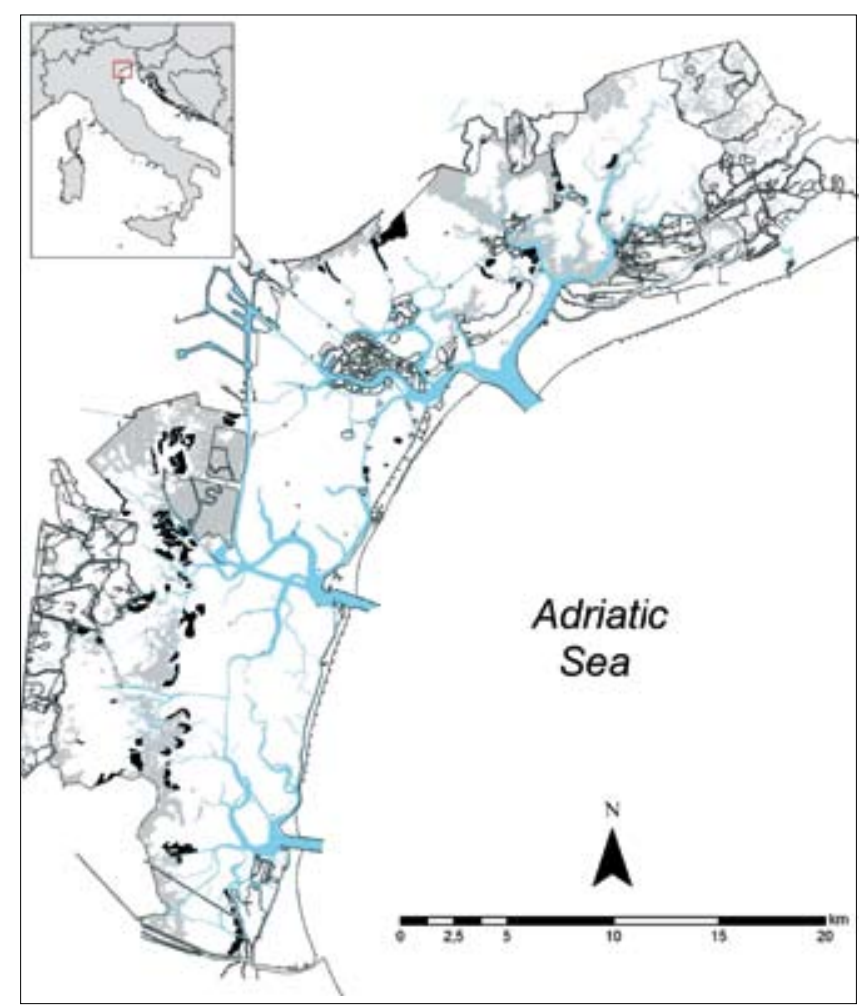

Fig. 1 - The lagoon of Venice, with saltmarshes (in grey) and dredge islands (in black). / La laguna di Venezia, con barene in grigio e barene artificiali in nero. refer to the Venice local datum) and the tidal range during spring tides is about $1 \mathrm{~m}$, with a mean tidal range of 0.6 $\mathrm{m}$, one of the highest observed in the whole Mediterranean (Ferrarin et al., 2013). The climate is temperate, with a mean annual temperature of $14.5^{\circ} \mathrm{C}$; rainfall is around $800 \mathrm{~mm}$ per year, with the peak in March and the minimum in May.

Salt marshes, which have elevation ranging from 0.5 to $0.7 \mathrm{~m}$, cover an area of about 3,800 hectares and are regularly flooded during mean high tides; only the highest spring tides cover salt marshes with at least $30-40 \mathrm{~cm}$ of water. Dominant plant species include Sarcocornia fruticosa, Salicornia veneta, Limonium narbonense, Halimione portulacoides and Puccinellia palustris.

The lagoon of Venice hosts important populations of waterbirds, both at national and Mediterranean level (Scarton, 2005). Seabird colonies are often mixed with other Charadriiformes, such as Redshank Tringa totanus, Avocet Recurvirostra avosetta and Black-winged Stilt $\mathrm{Hi}$ mantopus himantopus. Predators of eggs, chicks or adults include rats Rattus spp., but only at infrequently flooded sites, Marsh Harrier Circus aeruginosus, Montagu's Harrier Circus pygargus, and Peregrine Falcon Falco peregrinus (Valle \& Scarton, 1999). On salt marshes, seabirds build their nests mostly on mats of marsh debris, usually windrows of dead plants (such as reed Phragmites australis stems, large green algae, or leaves of seagrasses), laying on the top of salt marsh vegetation, resulting in the nests being well above $(>20 \mathrm{~cm})$ the saltmarsh surface. Of secondary importance are other nesting places, such as small, storm-deposited shell piles along marsh fringes. Blinds built by waterfowl hunters along the saltmarsh edge and surrounded by gravel or stones are also occasionally used by seabirds to nest.

Since 1985, about 120 dredge islands have been built in the lagoon, ranging in size from 0.4 to $57.4 \mathrm{ha}$, with a mean surface area of 11.2 ha and a total area in 2013 of about 1300 ha (Scarton et al., 2013). Dredge islands consist of a containment cell formed using wooden piles along the exterior. These areas of shallow water are then filled with sediments originating from the regular dredging of lagoon channels or inlets. After sediment compaction, these islands reach a mean elevation above sea level between 0.5 and $1.2 \mathrm{~m}$; for this reason, the area flooded by the high tides is variable, ranging from about $50 \%$ to almost $100 \%$. Throughout the years, remarkable modifications occur to the vegetation cover and structure of dredge islands. From almost a bare surface several phases lead to an almost continuous coverage of halophytes; shallow tidal ponds and creeks, both naturally formed and manmade, have a different extent and complexity at each site. These dredge islands are used by about hundred bird species throughout the year (Scarton \& Montanari, 2015).

Natural beaches are found along the Island of Lido, the southern tip of Pellestrina Island and along the whole peninsula of Cavallino; these beaches are up to $150 \mathrm{~m}$ wide. Between 1994 and 1998 an artificial beach was created through nourishment works along the sea side of the Pellestrina Island sea wall, with the use of 4,500,000 $\mathrm{m}^{3}$ of sand excavated some $\mathrm{km}$ offshore; this new beach has a total length of about $8 \mathrm{~km}$ and a width of $30-70 \mathrm{~m}$. 


\section{Survey methods}

Each year between 1989 and 2013 the whole lagoon, with the exception of fish farms but including the littoral strip, was searched by boat for nesting colonies. Two observers visited each colony at least twice during the peak breeding season (May-July). Surveys took place between 9:00 and 14:00 hours, avoiding days with unusually high tides, strong winds and rains. All apparently occupied nests (definition according to Steinkamp et al., 2003) were counted, with only the peak value of nests considered for each colony. The number of breeding pairs was assumed to be the same as the number of occupied nests, an assumption that may not always be valid (Frederick et al., 2006). Most of the colonies in our study area were not large (see Results), thus error due to detection probability was probably minimal. The most likely source of error is through birds nesting in one colony being unsuccessful then moving to another. To reduce this error, all the colonies occurring in the lagoon in a given year were surveyed whenever possible within two-week periods. Then, the highest number of pairs among those estimated in any two-week period was considered as the total population for that year. In thirteen cases colonies could not be approached and pairs were estimated at a distance by dividing the number of alarming birds by 1.5 , a ratio we checked several times at colonies regularly surveyed. The colonies of Yellow legged Gull Larus michahellis (hereafter YLG) occurring each year in two very large $(1,100$ ha overall) artificial islands made in the ' 60 s were quickly visited each year but were surveyed in only a few years, due to logistical constraints. For the years without surveys, only our estimates were used. Adults of Gull-billed Terns Gelochelidon nilotica were observed only sporadically, without proof of nesting and for this reason the species is not considered here. One lone breeding adult of Lesser crested Tern Sterna bengalensis mated with a Sandwich Tern (ST; Scarton et al., 2000) was also not considered.

Colony location was originally plotted on a $1: 10,000$ scale map, and in more recent years with the use of a portable GPS. In this paper a "breeding site" is considered a spatially well-defined place (salt marsh islet, dredge island, islet) used at least once by at least two breeding pairs.

For the analyses, non-parametric tests were used because counts of breeding pairs were not normally distributed. Differences between medians were tested with the use of Mann-Whitney and Kruskal-Wallis tests. We quantified diversity of the community by the mean of the Shannnon-Wiener index $\left(\mathrm{H}^{\prime}\right)$, calculated as as $\mathrm{H}^{\prime}=-\Sigma$ fri $\ln ($ fri $)$, where fri $=$ frequency of $i^{\text {th }}$ species. To analyze the population trends for the 1989-2013 years we used TRIM (Trends and Indices for Monitoring data), vers. 3.5, a free software package used to determine species' population trends (Pannekoek \& Van Strien, 2005). Using suggestions given by Vořišek et al. (2008), as we were dealing with complete counts, we used a Time Effects Model, with over dispersion set to "off" and serial correlation to "on".

Colony sites were grouped according to their origin and coded as "natural sites" (saltmarsh islets and natural beaches), "constructed sites" (dredge islands and artificial beaches) and "other artificial sites" (hunting blinds, very small islets, abandoned pontoons, etc.). The degree of dependence of breeding seabirds from constructed sites as nesting site was judged slightly modifying the criteria given by Soots \& Parnell (1975): i) heavily dependent, if more than $50 \%$ of estimated pairs nested at dredge islands; ii) moderately dependent, if nested between $10 \%$ and $50 \%$ of the pairs; iii) not dependent, if less than $10 \%$ of the pairs nested at dredge islands. We evaluated the degree of possible association among breeding seabirds using the following coefficient (Goutner, 1990): $\mathrm{Phi}=\mathrm{ad}-$ $b c /[(a+b)(c+d)(a+c)(b+d)]^{1 / 2}$, where $a=$ species $x$ and $\mathrm{y}$ are both present in a colony; $\mathrm{b}=$ species $\mathrm{x}$ absent, species y present; $\mathrm{c}=$ species $\mathrm{x}$ present, species y absent; $\mathrm{d}=$ both species absent. This coefficient may range between -1 (complete avoidance) and +1 (complete association). The significance for each combination of two species was examined by $2 \times 2$ Fisher exact probability test. Based on the observed Cramer's V values, the association was considered very weak $(<0.1)$, weak $(0.1-0.19)$, moderate (0.20-0.29), strong $(>0.30)$.

\section{RESULTS}

\section{Trends in population size and diversity}

Six species nested in the study area during the period 1989-2013 (Fig. 2): Black-headed Gull Chroicocephalus ridibundus (BHG), Mediterranean Gull Larus melanocephalus (MG), Yellow-legged Gull, Little Tern Sternula albifrons (LT), Sandwich Tern Sterna sandvicensis, Common Tern Sterna hirundo (CT).

Community size, i.e. total number of pairs, increased from 2011 in 1989 to 4,900 in 1999, and afterwards it fluctuated around this level. Richness increased slightly but significantly (Spearman test: $r_{s}=0.81, p<0.001$ ) from four species in the first years to six in 2012-2013. Despite the increase in richness, the population diversity has been always low, with values of the H' index ranging between 0.82 and 1.21, significantly decreasing over the years (Spearman test: $r_{\mathrm{s}}=-0.39, \mathrm{P}<0.05$ ).

YLG was always the most abundant species, with a peak of about 3700 pairs in 2006; it comprised about 40 to $76 \%$ of the whole community (Fig. 3).

This species showed a strong increase, with an annual rate of $+11.7 \%$, until 2002 and then leveled off at $3417 \pm 65.9$ pairs (mean + SE), with an annual increase close to zero. The YLG has been nesting mostly on two large artificial islands, but since 2006 dredge islands also support a stable population of $841.8 \pm 84$ pairs per year.

The second most abundant species, but only until the year 2000, was the CT with $989.8 \pm 61.7$. In the following years, the species underwent a severe decline, with only a partial rebound in the very last years of the survey. The CT occurs nowadays with about half the population size occurring at the beginning of the survey.

The ST settled in the lagoon for the first time in 1995, with 202 pairs; before that year, only summering adults were regularly observed. The number of breeding pairs rose up to 686 in 2001, with an annual rate of $+18.1 \%$; from 2002 till 2013 the population fluctuated around 
22

FRANCESCO SCARTON, ROBERTO VALLE
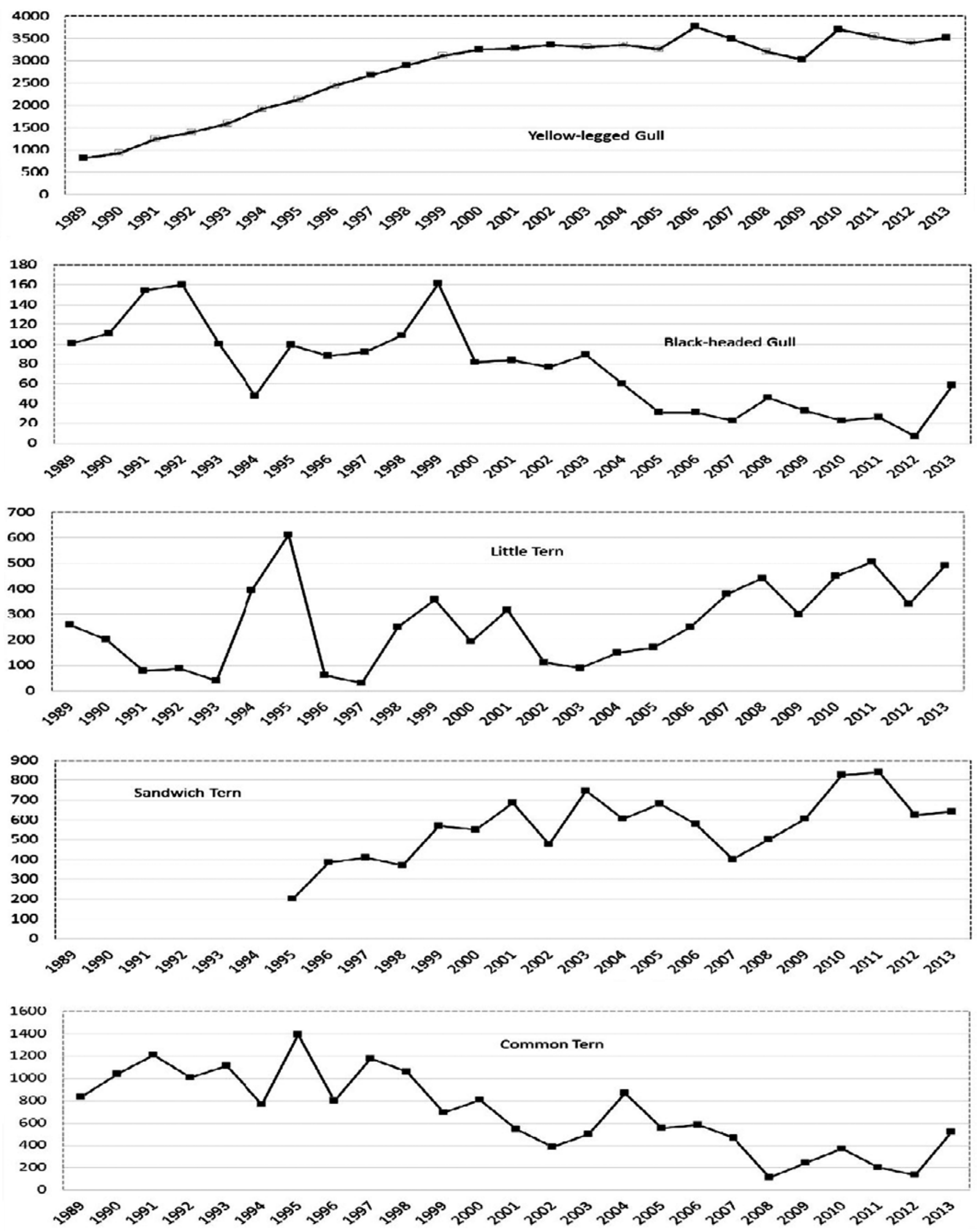

Fig. 2 - Size of each population, except Mediterranean Gull that start breeding in 2012. For the Yellow-legged Gull, solid dots indicate years with surveys and estimates, empty dots when only estimates are available. / Dimensioni di ciascuna popolazione, escluso il gabbiano corallino che ha nidificato per la prima volta nel 2012. Per il gabbiano reale, i pallini pieni indicano gli anni con censimenti e stime, quelli vuoti gli anni per i quali sono disponibili solo stime. 




Fig. 3 - Changes in species composition (\% of pairs) of the seabird community. / Cambiamenti nella composizione specifica (\% delle coppie) della comunità di uccelli marini.

$626.5 \pm 38.5$, with an annual increase of only $1.8 \%$. Since 2001 onwards, the ST became the second most abundant species in the lagoon. ST used only one breeding site for the first five years, with an increase in colony size of $22 \%$ per year; afterwards, one to five sites were used in a given year, and the founder-colony fluctuated widely, with an annual increase of $4.5 \%$. Among the other species, the LT was characterized by irregular fluctuations between 1989 and 2002, and then it began to increase more regularly and leveled off at $417.2 \pm 41.1$ pairs in the last five years. The
BHG fluctuated around 100 pairs until 1999, afterwards it decreased dramatically and in the last five years only $29.4 \pm 8.3$ pairs were breeding. The last species to settle in the lagoon was the MG, with a large colony of 350 pairs, which appeared in 2012, but only 8 pairs nested in 2013 . The sudden arrival of hundreds of nesting adults is similar to what already observed for ST.

Population trends for five species (excluding the MG, whose settlement is too recent) and for the whole community are shown in Tab. 1.

Tab. 1 - Population trends for the seabirds nesting in the lagoon of Venice assessed with TRIM software. Yearly variation and significance level are also shown. / Andamenti di popolazione degli uccelli marini nidificanti nella laguna di Venezia elaborati con il software TRIM. Si mostrano anche la variazione percentuale annuale e il livello di significatività.

\begin{tabular}{|l|l|c|c|}
\hline & \multicolumn{3}{|c|}{ 1989-2013 } \\
\hline & Trend & Var. \% & P \\
\hline Yellow-legged Gull & Strong increase & +5.2 & $<0.01$ \\
\hline Black-headed Gull & Strong decline & -7.9 & $<0.01$ \\
\hline Little Tern & Strong increase & +5.5 & $<0.05$ \\
\hline Sandwich Tern & Moderate increase & +6.2 & $<0.01$ \\
\hline Common Tern & Strong decline & -7.3 & $<0.01$ \\
\hline Total pairs & Moderate increase & +3.1 & $<0.01$ \\
\hline Total pairs without Yellow-legged Gull & Moderate increase & +0.2 & $<0.05$ \\
\hline
\end{tabular}


Colony sites and colonies' characteristics

The following results refer only to the five species that were surveyed in detail and thus do not include YLG colonies. During 25 years, 119 colony sites were used at least once; in each year, the number of sites used by seabirds ranged between 6 and 24, with a mean of $13.8( \pm 4.6, S D)$. Each site was used for 1-20 years, not necessarily continuously, with a mean of 2.8 years $( \pm 3.29)$ and a median of 2 years; about $83 \%$ of the sites were used in $\leq 3$ years. The maximum values refer to saltmarsh sites, which were used in 20,19 and 15 years respectively.

From 1989 to 2013, 346 colonies were surveyed, ranging in size from 2 to 1337 pairs (mean \pm SD: $106.4 \pm 171.6$, median: 41). Colonies were significantly larger (KruskalWallis: $\mathrm{H}=39.95, \mathrm{P}<0.001$, d.f.=2) on natural sites (median: 62 nests) than on constructed sites (20.5) or other artificial sites (10). Colonies size varied significantly (Kruskal-Wallis: $\mathrm{H}=96.1, \mathrm{P}<0.001$, d.f.=4) among species, with ST having the largest size and BHG the smallest (Tab. 2).
Between 1989 and 1997 "natural sites", several marsh islets and a few beaches, made up the large majority of colony sites, with a few "other artificial sites" used only irregularly (Fig. 4). From 1998 onwards, natural beaches were almost completely abandoned, with only a few pairs occasionally nesting there, whereas marsh islets kept on being used, but with decreasing importance.

Proportions of pairs (all the species pooled, YLG excluded) nesting at "natural sites" went from $100 \%$ in 1989 , to $96 \%$ in 2000 and $50 \%$ in 2013 ; in the same years the percentages of pairs breeding at "constructed sites" were $0,3 \%$ and $42 \%$, respectively. Species differed in their use of sites (Fig. 5): LT showed the highest use of constructed sites (overall, $60 \%$ of pairs nested at these sites), whereas BHG and ST never used them. Differences among species in the number of pairs nesting at each typology were highly significant $\left(\chi^{2}: 17,930\right.$; d.f.: $\left.6, \mathrm{P}<0.001\right)$.

In 1998 a few dredge islands were used for the first time by this species, and since then the use of this type of site becomes more and more relevant. The proportion of

Tab. 2 - Number and characteristics (no. of pairs) of seabird colonies surveyed between 1989 and 2013. / Caratteristiche delle colonie di uccelli marini censite tra il 1989 ed il 2013.

\begin{tabular}{|l|c|c|c|c|c|}
\hline & Black-headed Gull & Mediterranean Gull & Little Tern & Sandwich Tern & Common Tern \\
\hline N. & 87 & 2 & 146 & 42 & 235 \\
\hline Min & 2 & 8 & 2 & 5 & 2 \\
\hline Max & 138 & 350 & 481 & 820 & 583 \\
\hline Mean & 21.7 & 179 & 44.8 & 254.5 & 73.7 \\
\hline SE & 2.77 & 171 & 5.12 & 33.4 & 5.69 \\
\hline SD & 25.9 & 241.8 & 61.9 & 216.5 & 87.2 \\
\hline Median & 12 & 179 & 22 & 190 & 40 \\
\hline
\end{tabular}

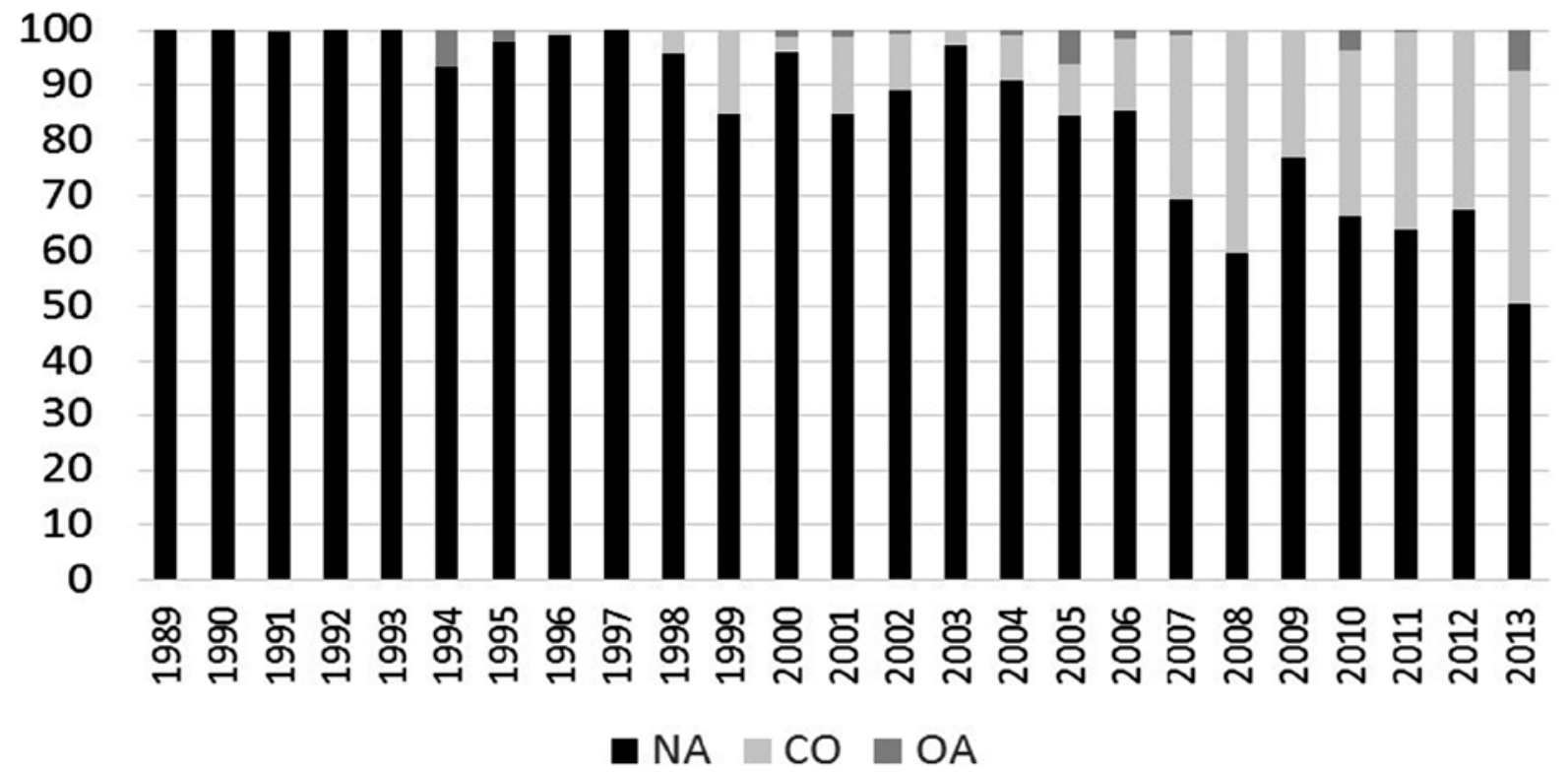

Fig. 4 - Type of colony site and \% of the total population (YLG excluded) nesting there. NA, Natural sites; CO, Constructed sites; OA, Other artificial sites. / Tipologia di sito di nidificazione e \% della popolazione totale, escluso il gabbiano reale, che vi ha nidificato. NA, siti naturali; $\mathrm{CO}$, barene e spiagge artificiali; $\mathrm{OA}$, altri siti artificiali. 


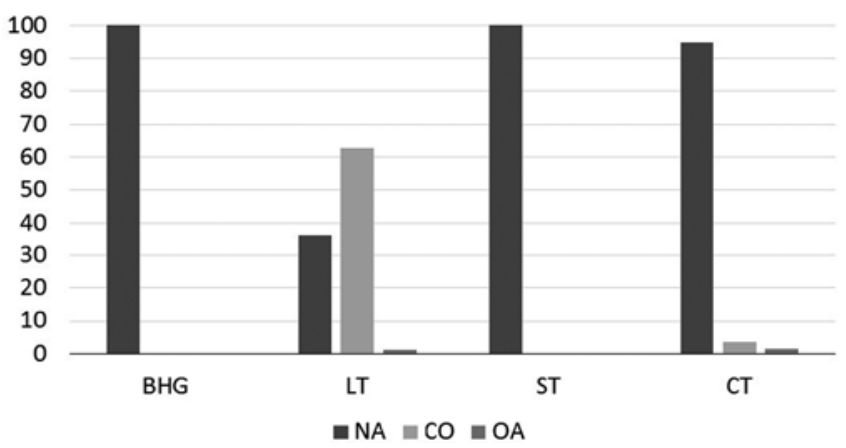

Fig. 5 - Percentage of pairs of four species, all the years pooled, nesting at each different colony site type. NA, Natural sites; CO, Constructed sites; OA, Other artificial sites. / Percentuali di coppie nidificanti, anni raggruppati, nelle diverse tipologie di siti. NA, siti naturali; $\mathrm{CO}$, barene e spiagge artificiali; OA, altri siti artificiali.

LT pairs nesting on this typology has been regularly increasing: from 2010 onwards all the nesting population of LT moved to these sites, abandoning salt marsh islets. The CT began to nest on dredge islands much later, in 2005; in more recent years up to $40 \%$ of the population moved from saltmarsh islets to dredge islands. Until 2013, neither ST nor MG used this kind of site; nevertheless, after the survey period (in 2014) a colony of 659 ST pairs settled on a dredge island for the first time. According to these results, LT may be classified as "heavily dependent" for nesting on artificial sites, while the remaining three species were "not dependent" on them.

Site occupancy (i.e. number of years) varied among site typology, but not significantly (Kruskal-Wallis $\mathrm{H}=0.91$, NS, d.f.=2). Nevertheless, colony size were greatly different, with colonies on natural sites being much bigger (median: 62 nests) than on constructed sites (21 nests) or other artificial sites (10 nests); differences were highly significant (Kruskal-Wallis $\mathrm{H}=40.76, \mathrm{P}<0.001$, d.f. $=2$ ).

Considering all the colonies (excluding the two of $\mathrm{MG})$, the degree of association between species ranged from "weak" to "strong" for CT, ST and BHG; only LT exhibited a strong negative association with the other three species, in particular with $\mathrm{CT}$ (Tab. 3).

\section{DISCUSSION}

The seabird community of the lagoon of Venice totaled six species over the study period; other western Mediterranean coastal wetlands are richer in seabirds, since the Comacchio wetlands ( $80 \mathrm{~km}$ south of Venice) host nine species (Brichetti \& Foschi, 2006), the Camargue eight
(Kayser et al., 2014) and the Ebro Delta nine to twelve (Oro et al., 2009). Numbers of breeding pairs at those wetlands are also larger, sometimes much larger, respect to our study area. Compared to the other coastal wetlands, the Venice lagoon lacks the Slender billed Gull Larus ge$n e i$, certainly due to the total absence of saltpans or other highly saline environment, feeding habitat of paramount importance for this species (Oro, 2002). Moreover, the lagoon of Venice lies well above the northern limit of the breeding area for the Audouin's Gull Larus audouinii, thus its absence may be explained by biogeographical reasons. Instead, the Gull-billed Tern nested occasionally in the fish farms, not included in our study area, with only a few pairs in the very last years (Bon et al., 2014); the scarcity of this species in the whole lagoon of Venice is difficult to explain given the apparent high availability of suitable breeding and feeding habitats.

The six-species seabird community we studied shows a moderate increase over the 25 years, which become much slower in the last ten years; this was due to the strong increase of YLG observed only in the first years of the survey.

From 2000 onwards, the community became dominated by YLG and ST, which altogether made in the following years more than $80 \%$ of the total number of pairs. Consequently, the community diversity, which was never high, decreased significantly in the same period.

Detailed data presented by Brichetti \& Foschi (2006) for the Comacchio lagoon allow comparisons between that site and the Venice lagoon, at least for the years 1989-2001. In this period Comacchio had a higher diversity (mean $H^{\prime}=1.65$ ) and about 1,000 more breeding pairs. In the same period, Comacchio experienced a significant reduction in the total number of breeding pairs $\left(\mathrm{r}_{\mathrm{s}}=-0.74\right.$, $\mathrm{P}<0.01)$. Part of this reduction concerns STs, which at least in part moved to the lagoon of Venice: the ST population trends between the two wetlands are significantly, and negatively, correlated $\left(\mathrm{r}_{\mathrm{s}}=-0.83, \mathrm{P}<0.001\right)$. This suggests the northern Adriatic hosts a metapopulation of ST; the Po Delta works as a source and the Venice lagoon as a sink. Nevertheless, observation in the Venice lagoon colonies of ST adults ringed in Ukraine (R. Rusticali, pers. comm.) or in Spain, Scotland and Denmark (Accipiter, 2012) indicates that breeding adults may not come only from Adriatic colonies.

During our 25-year survey, we recorded the settlement of two new species (ST and MG) whereas no species became extinct. The opportunity of documenting formation and growth of new colonies is quite uncommon in seabirds, due to their high breeding philopatry (Kildaw et al., 2005). As observed elsewhere for other seabirds (Oro \&

Tab. 3 - Cramer $\mathrm{V}$ and significance level $(* \mathrm{P}<0.05 ; * * \mathrm{P}<0.01 ; 346$ colonies considered) of association observed between species. / Coefficiente V di Cramer e livello di significatività $\left({ }^{*} \mathrm{P}<0.05 ; * * \mathrm{P}<0.01,346\right.$ colonie) per l'associazione osservata tra specie.

\begin{tabular}{|l|c|c|c|}
\hline & Common Tern & Sandwich Tern & Little Tern \\
\hline Black-headed Gull & $0.22^{* *}$ & $0.41^{* *}$ & $-0.26^{* *}$ \\
\hline Common Tern & & $0.21^{* *}$ & $-0.64 * *$ \\
\hline Sandwich Tern & & & $-0.13^{*}$ \\
\hline
\end{tabular}


Ruxton, 2001), the new colony of ST grew rapidly in the first years, attracting bird emigrating from other wetlands. After five years, the ST population began to use additional colony sites, mostly at less than $10 \mathrm{~km}$ from the first one. Since feeding habitats were likely to be overlapping among adults nesting each year in the different sites, we deem the main reason for the formation of new colonies to be a decrease in habitat quality of the first colony site. This was due to a reduced availability of suitable nesting sites, and not to intraspecific food competition (the adults kept on feeding on the same waters) or predation (which was always negligible). The highly irregular trend shown by breeding adults nesting in the following years in the first colony site, ranging from 5 to 820 pairs, shows the occurrence of some unpredictable factor, which altered the availability of suitable nest sites; more detailed analyses are needed to enlighten these factors.

The YLG population, after about ten years of continuous growth, is nowadays stable; in the last two decades some garbage dumps located in the close mainland of the lagoon of Venice were closed down, which certainly reduced the food available for adults and chicks. Studies made by Soldatini et al. (2005) showed that YLG breeding in the lagoon also forage on garbage. According to our field observations, the two large islands used as colony sites appear to have reached their maximum capacity; this prompted the YLG to nest in the historical town of Venice, with less than 100 pairs estimated recently (Bon et al., 2014), and especially on dredge islands, with 420-1000 pairs in the 2009-2013. It is remarkable, in this process of colonization of new sites that YLG has been almost completely absent from saltmarsh islets, indicating a strong avoidance by this species for sites prone to flooding. This confirms the attraction of the YLG for stable and predictable nesting habitats (Almaraz \& Oro, 2011).

The observed reduction of BHG is certainly due to the moving of most of the adults from the southern lagoon to two fish farms located in the northern lagoon, about 30 $\mathrm{km}$ away (pers. obs.). We cannot be confident the same holds true for the CT, the only other species that abandoned most of the colony sites previously occupied.

Contrastingly, LT increased with a striking $+12.3 \%$ annually over the last ten years. In twelve years, all the LT colonies moved from saltmarsh islets to dredge islands, whereas only a minor portion of CTs made the same. LT is known to use readily artificial sites such as salt ponds, heaps of gravel and/or sand, even building roofs (Fujita et al., 2009); in the Lagoon of Venice dredge islands, being almost bare in their first years and slightly more elevated than saltmarsh islets, are suitable nesting sites for this species (Scarton, 2008b). Probably due to a higher breeding philopatry (Tims et al., 2004), CT was less prone to abandon saltmarsh islets; elsewhere, the rapid use of artificial islands by this species has been well documented (Schippers $e t$ $a l ., 2009)$. Remarkably, only at the end of our survey did the species begin to use dredge islands, and this led to the observed partial rebound in breeding numbers.

In the lagoon of Venice the large use of dredge islands made by LT, compared to the very small, if any, by the other species, explains the results of the association analysis; these showed a significant avoidance of LT for the other islands. Similar lack of association was observed by Goutner (1990) in Greek wetlands and by Fasola \& Canova (1991) in the Comacchio lagoon.

We deem an important driving force causing the observed movement of colonies from saltmarsh islets to dredge islands is the increase of the mean sea level which occurred in the lagoon of Venice, totaling about $18 \mathrm{~cm}$ from 1989 to 2013 (data from Comune di Venezia, 2014). Beside the increase in the mean annual level an even more important aspect is the number of tides exceeding $0.80 \mathrm{~m}$ (a level from which we estimate nests become flooded) that occur in the peak nesting period, i.e. May-July. Being almost absent at the beginning of the survey, in the last years tides of this amplitude observed in May-July increased up to fivesix times, which caused repeated flooding of saltmarshes and colony disruption. According to our field observations, flooding and over-washing caused by spring storms are the most important causes of reproductive failure at the colonies of the Venice lagoon, as observed at other coastal wetlands (Erwin et al., 2006; Jodice et al., 2007). It is still worthy of note, given the observed increase in flooding frequency, that several hundred of STs had been nesting continuously on the same saltmarsh islet for 19 years.

Saltmarshes are inherently unstable as colony sites (Visser \& Peterson, 1994; Oro et al., 2011); in our study area we observed the frequent change of sites, but at a same time a few other colonies settled for more than a decade on the same islets. Specific management activities devoted to these "traditional" sites may thus guarantee suitable nesting site for a significant fraction of the nesting population.

The changes in the seabird composition, i.e. heavy reduction of CT and concomitant increase of ST, indicate a shift over the last 25 years towards a more "pelagic" assemblage. ST is known to feed largely on coastal waters, sea inlets etc., more than CT or LT, as observed by Fasola \& Bogliani (1990) in the Po Delta. Boat transects made in the southern Lagoon of Venice and close marine waters up to a distance of five $\mathrm{km}$ from the littoral strip (Scarton, 2008a) confirmed that ST was the species more often observed feeding in the open sea, often the only one. Since in the lagoon most seabird colonies were located at a minimum distance of $5 \mathrm{~km}$ from the open sea (in the last ten years all colonies), and given the feeding range observed elsewhere in the Adriatic for CT $(<8 \mathrm{~km})$ and LT $(<4 \mathrm{~km}$; Fasola \& Bogliani, 1990), it is very unlikely that open sea may constitute an important feeding habitat for these two species. They have thus to rely on lagoon waters for their feeding activity. The strong decline shown by CT could be due to a reduction of preys occurrence and/or availability in the lagoon waters, but the population rebounds shown as soon as the species began to nest on dredge islands suggests that a decrease in colony site quality (due to frequent flooding) should be also considered among the main causes.

Alternative explanation such as competition for nesting sites, which often is a cause of population decrease for some seabirds (Almaraz \& Oro, 2011) is not likely in our study area, where the more abundant, large and aggressive Yellow-legged Gull makes a very occasional use of saltmarshes on which to nest. Again, we did observe ST displacing CT from their already occupied nest sites, but 
this happened on just one site, so it cannot be assumed as a cause of population decrease in the latter species.

With a few relevant exceptions, colony sites in our study area were used for very few years, which indicate a low site fidelity. The low site fidelity has been attributed to the high availability of alternative sites, or to high instability of sites (Sadoul et al., 1996). In the lagoon of Venice thousands or saltmarsh islets exist, all of them apparently suitable. Nevertheless, at a more refined scale, the morphological key feature to make an islet suitable as a possible site is the occurrence of wind wracks and/ or shell piles at the start of the breeding season. These microhabitats occupy only a very small percentage of a saltmarsh area, and their occurrence among saltmarsh islets, in particular that of wind wracks, varies over the years. Since only 68 different saltmarsh sites were used at least once in 25 years, we may conclude that only a small fraction of the existing islets was really suitable for birds. Birds used these sites over the years, most likely according to the annual availability of wind wracks and/or shell piles. This has important consequences in adopting possible management options (see Conclusions).

The assessment of the national and international relevance of the populations nesting in the lagoon of Venice is hampered by objective difficulties due to the poor quality of data available in the scientific literature. After the first Italian survey made in 1982-84 (Fasola, 1986), there has not been any other nationwide census. Even the recent Report to the European Community on the Status of Annex 1 Species (ISPRA, 2014) still quotes only estimates referring to the beginning of this century and made by Brichetti \& Fracasso (2006). Put in other words, we do not know how many terns and gulls nested in the past years in Italy. With these considerations in mind, we may only estimate that five species exceed the $5 \%$ threshold of the respective Italian populations: YLG, MG, ST, CT and LT. The largest fraction refers to the ST, about $80 \%$ of the national total, followed by a $15 \%$ for the LT.

On the grounds of our field data, populations of both species appear well established in the lagoon of Venice and we did not observe any directly significant man-induced disturbance to their colonies. Therefore, we strongly disagree with the "serious threat" advocated by Peronace et al. (2012) for the ST nesting in the lagoon of Venice. Indeed, it is likely that the Venice lagoon hosts one of the healthiest and largest breeding populations of ST along the Western Mediterranean, if compared to the $0-1,300$ pairs counted in the Camargue during 2007-2012 (Kayser et al., 2014), the 400-800 in the Ebro Delta in 2009-2010 (Almaraz \& Oro, 2011) and the 1,355-1,591 at Albufera de Valencia in 2001-2003 (Dies \& Dies, 2004).

Finally, given the high conservation values of these two species, they deserve regular monitoring and proper management at a local scale in order to maintain the importance at national and international level of the Venice lagoon.

\section{CONCLUSIONS}

In order to link the observed changes in community size to possible causal factors, a second step besides counting nesting pairs is setting up studies on the use of feeding habitats, reproductive success and diet composition at selected colonies.

Management activities should be targeted differently at natural and man-made sites. Therefore, on saltmarsh islets creation and consolidation of shells heaps at colony sites already used in the past should be highly effective in providing birds with traditional nesting microhabitats and more able to cope with high tides. Moreover, heaps of dead sea grasses or straw attached to the ground could be located in the inner parts of the saltmarshes. A few experimental works were done in the past in the lagoon of Venice, with good success (Scarton et al., 1995) but without continuation in the following years. Particular attention should be devoted to the conservation of the very few saltmarsh sites, which were used for more than 10 years and where large colonies of seabirds settled. At these sites, additional and more intensive work targeted at the protection against erosion due to waves and tidal currents should be carried out.

At dredge islands it is more important to counteract vegetation overgrowth, making vegetation cutting and surficial soil tilling targeted at selected parcels of sites already used by seabirds in the past. Moreover, small heaps of shell fragments mixed with sand could be provided at newly built dredge islands, which very often proved to be quickly used by Little Terns and other Chadriiformes of conservation concern.

\section{Acknowledgments}

Large part of the data were gathered within monitoring projects carried out for the Provveditorato Interregionale per le Opere Pubbliche per il Triveneto - Ministero dei Lavori Pubblici (Italian Ministry of Public Works) through its concessionary Consorzio Venezia Nuova. The assistance of F.M. Baglio, G. Cecconi, C. Cerasuolo, P. Nascimbeni is warmly acknowledged. In seven years surveys were self-financed, whereas data for the 2013 were collected for the CORILA-Consorzio per la Gestione del Centro di Coordinamento delle Attività di Ricerca inerenti il Sistema Lagunare di Venezia; the assistance of C. Dabalà was very helpful. M. Baldin, P. Bertoldo, S. Borella, E. Checchin, D. Smania were of great help during field visits. Thanks to Professor W.G.Hale (Liverpool Polytechnic, UK) for revising the English text. Two anonymous referees greatly improved the manuscript.

\section{REFERENCES}

Accipiter (associazione naturalistica), 2012 - Le migrazioni degli uccelli in provincia di Venezia. Amministrazione della Provincia di Venezia.

Almaraz P. \& Oro D., 2011 - Size mediated non trophic interactions and stochastic predation drive assembly and dynamics in a seabird community. Ecology, 92: 1948-1958.

Atkinson P.W., Austin G.E., Rehfisch M.M., Baker H., Cranswick P., Kershaw M. \& Maclean I.M.D., 2006 - Identifying declines in waterbirds: the effects of missing data, population variability and count period on the interpretation of long-term survey data. Biological Conservation, 130: 549-559.

Bon M., Scarton F., Stival E., Sattin L. \& Sgorlon G., 2014 - Nuovo Atlante degli uccelli nidificanti e svernanti in provincia di Venezia. Associazione Faunisti Veneti, Museo di Storia Naturale di Venezia. 
Brichetti P. \& Foschi U.F., 2006 - Evoluzione delle popolazioni di Laridae e Sternidae nidificanti nelle Valli di Comacchio nel periodo 1977-2001. Avocetta, 30: 41-50.

Brichetti P. \& Fracasso G., 2006 - Ornitologia italiana. 3. Stercorariidae-Caprimulgidae. Alberto Perdisa Editore, Bologna.

Clutton-Brock T. \& Sheldon B., 2010 - Individuals and populations: the role of long-term, individual-based studies of animals in ecology and evolutionary biology. Trends in Ecology and Evolution, 25: $562-573$.

Comune di Venezia, 2014 - Istituzione Centro Previsioni e Segnalazioni Maree. <http://www.comune.venezia.it> (Retrieved on October 2014).

Dies J.I. \& Dies B., 2004 - Breeding biology and colony size of Sandwich Tern at l'Albufera de Valencia (Western Mediterranean). Ardeola, 51: 431-435.

Erwin R.M., Sanders G.M., Prosser D.J. \& Cahoon D.R., 2006 - High tides and rising seas: potential effects on estuarine waterbirds. Studies in Avian Biology, 32: 214-228.

Fasola M. (ed.), 1986 - Distribuzione e popolazione dei Laridi e Sternidi nidificanti in Italia. Istituto nazionale di biologia della selvaggina, Supplemento Ricerche di Biologia della Selvaggina, Ozzano dell'Emilia, 11.

Fasola M. \& Bogliani G., 1990 - Foraging Ranges of an Assemblage of Mediterranean Seabirds. Colonial Waterbirds, 13: 72-74.

Fasola M. \& Canova L., 1991 - Colony site selection by eight species of gulls and terns breeding in the "Valli di Comacchio" (Italy). Italian Journal of Zoology, 58: 261-266.

Ferrarin C., Ghezzo M., Umgiesser G., Tagliapietra D., Camatti E., Zaggia L. \& Sarretta A., 2013 - Assessing hydrological effects of human interventions on coastal systems: numerical applications to the Venice Lagoon. Hydrology and Earth System Sciences, 17: $1733-1748$.

Frederick P., Heath J, Bennetts R. \& Hafner H., 2006 - Estimating nests not present at the time of breeding surveys: an important consideration in assessing nesting populations. Journal of Field Ornithology, 77: 212-219.

Fujita G., Totsu K., Shibata E., Matsuoka Y., Morita H., Kitamura W., Kuramoto N., Masuda N. \& Higuchi H., 2009 - Habitat management of Little Terns in Japan's highly developed landscape. Biological Conservation, 142: 1891-1898.

Goutner V., 1990 - Habitat Selection of Little Terns in the Evros Delta. Waterbirds, 13: 108-114.

Istituto Superiore per la Protezione Ambientale (ISPRA), 2014 - Italy. Annex 2: Bird species' status and trends reporting format for the period 2008-2012. <http://cdr.eionet.europa.eu/IT_birds_reports> (retrieved on December 2014).

Jodice P.G.R., Murphy T.M., Sanders F.J. \& Ferguson L.M., 2007 Long-term Trends in Nest Counts of Colonial Seabirds in South Carolina, USA. Waterbirds, 30: 40-51.

Kayser Y., Blanchon T., Galewski T., Gauthier-Clerc M., Poulin B., Thibault M., Massez G., Tiné R., Sadoul N., Pin C., Chérain Y., Vandewalle P., Vialet E., Paulus G., Vincent-Martin N., Ponchon C., Pilard P., Flitti A., Isenmann P. \& Béchet A., 2014 - Compte-rendu ornithologique Camargue-Crau-Alpilles pour les années 20072012. Tour du Valat \& SNPN/Réserve nationale de Camargue.

Kildaw S.D., Irons D.B., Nysewander D.R., \& Buck C.L., 2005 - Formation and growth of new seabird colonies: the significance of habitat quality. Marine Ornithology, 33: 49-58.

Lindenmayer D.B. \& Likens G.E., 2010 - The science and application of ecological monitoring. Biological Conservation, 143: 1317-1328.

O'Connor R.J., 1991 - Long-term bird population studies in the United States. Ibis, 133 (s1): 36-48.

Oro D., 2002 - breeding biology and population dynamics of slenderbilled gulls at the Ebro Delta (Northwestern Mediterranean). Waterbirds, 25: 67-77.

Oro D., \& Ruxton G.D., 2001 - The formation and growth of seabird colonies: Audouin's gull as a case study. Journal of Animal Ecology, 70: 527-535.

Oro D., Pérez-Rodríguez A., Martínez-Vilalta A., Bertolero A., Vidal F. \& Genovart M., 2009 - Interference competition in a threatened seabird community: a paradox for a successful conservation. Biological Conservation, 142: 1830-1835.
Oro D., Tavecchia, G. \& Genovart, M., 2011 - Comparing demographic parameters for philopatric and immigrant individuals in a long-lived bird adapted to unstable habitats. Oecologia, 165: 935-945.

Pannekoek J. \& van Strien A.J., 2005 - TRIM 3 Manual. Trends and indices for monitoring data. Research paper no. 0102. CBS. Statistics Netherlands, Voorburg, The Netherlands.

Peronace V., Cecere J., Gustin M. \& Rondinini C., 2012 - Lista rossa 2011 degli uccelli nidificanti in Italia. Avocetta, 36: 11-58.

Sadoul N., Johnson A.R., Walmsley J.G. \& Levêque R., 1996 - Changes in the numbers and the distribution of colonial Charadriiformes breeding in the Camargue, Southern France. Colonial Waterbirds, 19: 46-58

Scarton F., 2005 - Breeding birds and vegetation monitoring in recreated salt marshes of the Venice Lagoon. In: Flooding and environmental challenges for Venice and its Lagoon. State of knowledge. Fletcher C.A. \& Spencer T. (eds.). Cambridge University Press, Cambridge: 573-579.

Scarton F., 2008a - Distribuzione ed abbondanza di Laridi e Sternidi sugli spazi acquei della laguna di Venezia. In: Atti V Convegno Faunisti Veneti. Bon M., Bonato L. \& Scarton F. (eds.). Bollettino del Museo Civico di Storia Naturale di Venezia, 58: 195-207.

Scarton F., 2008b - Population trend, colony size and distribution of Little Terns in the Lagoon of Venice (Italy) between 1989 and 2003. Waterbirds, 31: 35-41.

Scarton F., 2010 - Long-term decline of a Common Tern (Sterna hirundo) population nesting in salt marshes in Venice lagoon, Italy. Wetlands, 30: 1153-1159.

Scarton F. \& Montanari M., 2015 - Use of artificial intertidal sites by birds in a Mediterranean Lagoon and their importance for wintering and migrating waders. Journal of Coastal Conservation, 19: 321-334.

Scarton F., Borella S., Borgoni N., Richard J. \& Semenzato M., 1995 Interventi sperimentali per favorire la nidificazione di larolimicoli su barene artificiali in laguna di Venezia. Avocetta, 19: 26.

Scarton F., Valle R. \& Rusticali R., 2000 - New breeding site of Lesser Crested Tern in Italy. British Birds, 93: 448-451.

Scarton F., Cecconi G., Cerasuolo C. \& Valle R., 2013 - The importance of dredge islands for breeding waterbirds. A three-year study in the Venice Lagoon (Italy). Ecological Engineering, 54: 39-48.

Schippers P., Snep R., Schotman A.G., Jochem R., Stienen E.W.M. \& Slim P.A. 2009 - Seabird metapopulations: searching for alternative breeding habitats. Population Ecology, 51: 459-470.

Sergeant C.J., Moynahan B.J. \& Johnson W.F., 2012 - Practical advice for implementing long-term ecosystem monitoring. Journal of Applied Ecology, 49: 969-973.

Soldatini C., Riccato F., Torricelli P. \& Mainardi D., 2005 - Yellowlegged gull's diet and foraging location. $15^{\text {th }}$ Meeting of the Italian Society of Ecology, 12-14 September 2005, Torino, Italy.

Soots R.F. \& Parnell J.F., 1975 - Ecological succession of breeding birds in relation to plant succession on dredge islands in North $\mathrm{Ca}-$ rolina. UNC Sea Grant Publication UNC-SG-25-27.

Steinkamp M., Peterjohn B., Byrd V., Carter H. \& Lowe R., 2003 Breeding season survey techniques for seabirds and colonial waterbirds throughout North America. < http://www.waterbirdconservation.org./pubs/PSGManual03.PDF>

Tims J., Nisbet I.C.T., Friar M.S., Mostello C. \& Jeremy J., 2004 Hatch characteristics and performance of common Terns in old and newly-established colonies. Waterbirds, 27: 321-332.

Tourenq C., Bennetts R.E., Sadoul N., Mesleard F., Kayser Y. \& Hafner H., 2000 - Long-term population and colony patterns of four species of tree-nesting Herons in the Camargue, South France. Waterbirds, 23: 236-240.

Valle R. \& Scarton F., 1999 - The presence of conspicuous associates protects nesting Redshank Tringa totanus from aerial predators. Ornis Fennica, 76: 145-148.

Vořišek P., Klvaňova A., Wotton S. \& Gregory R.D. (eds.), 2008 - A best practice guide for wild bird monitoring schemes. First edition. CSO/RSPB.

Visser, J. M. \& Peterson G.W., 1994 - Breeding populations and colony site dynamics of seabirds nesting in Louisiana. Colonial Waterbirds, 17: 146-152.

Associate Editor: Ugo Mellone 